\title{
The efficacy of different postharvest treatments on physico-chemical characteristics, bioactive components and microbiological quality of fresh blueberries during storage period
}

\author{
*Chiabrando, V., Peano, C. and Giacalone, G. \\ DISAFA, Department of Agriculture, Forest and Food Science, Largo Braccini 2, 10095, Grugliasco (TO), \\ Italy
}

\begin{abstract}
Article history:
Received: 30 June 2017

Received in revised form: 28 July 2017

Accepted: 28 July 2017

Available Online: 30 July 2017
\end{abstract}

\section{Keywords:}

Blueberry,

Chlorine dioxide,

Electrolyzed water,

Quality,

Postharvest

\begin{abstract}
In recent years, there is increasing consumption and interest in berry fruits in general and blueberries in particular due to their nutritional and health characteristics. However, blueberries are highly susceptible to microbial contamination and loss of product quality. In this study, the effects of postharvest washing treatment and cold storage (15 days) on the quality of blueberries were examined. The blueberries were treated with mineral water, aqueous chlorine dioxide, electrolyzed water and Berry Very ${ }^{\circledR}$, a new commercial product. During the storage, physicochemical and microbiological analysis were carried out in order to compare the efficacy of treatments. The results indicated that chlorine dioxide treatment and electrolyzed water had a positive effect on the reduction of yeast and mold proliferation, postharvest decay and weight loss.
\end{abstract}

DOI:

http://doi.org/10.26656/

fr.2017.6.105

\section{Introduction}

Blueberry is a popular and attractive fruit with high visual appeal and nutritional values. Blueberries are rich in bioactive compounds such as anthocyanins and other flavonoids (Bunea et al., 2013, Chiabrando and Giacalone, 2015) but are highly susceptible to water loss, mechanical damage, physiological disorders, rapid spoilage and fungal proliferation during post-harvest storage period (Cantín et al., 2012). The short postharvest life limits their fresh market potential and consumer access (Duan et al., 2011). Several preservation technologies, including cold storage (Connor et al., 2002), high oxygen atmospheres storage (Zheng et al., 2003), ozone (Chiabrando et al., 2006) modified atmosphere packaging (Cantín et al., 2012), hot water treatments (Fan et al., 2008) and edible coatings (Chiabrando and Giacalone, 2016) have been studied to maintain fruit firmness, reduce deterioration and prolong the shelf-life of fresh blueberries.

Chlorine and chlorine-containing compounds are the products most frequently used to sanitize in the fruit industry. However, chlorine reacts with organic compounds and forms carcinogenic trihalomethanes and haloacetic acids, which are dangerous to people and environment (Keskinen et al., 2009). Compared to chlorine, chlorine dioxide has a lower oxidative potential but higher oxidation capacity and sterilizing power, which is found to visibly extend the postharvest life of numerous fruits and vegetables (Chen et al., 2011, Fangxu et al., 2016). Unlike chlorine, chlorine dioxide does not oxidize organic matters to producing toxic molecules (Gómez-López et al., 2009), so the use of $\mathrm{ClO}_{2}$ was approved by the Food and Drug Administration to sanitize fruit and vegetables. In current years, it has been studied that aqueous $\mathrm{ClO}_{2}$ is well used to reduce microorganisms and preserve the postharvest quality of many fruits like strawberries, plums, melon and apples (Du et al., 2002; Chen and Zhu, 2011; Shin et al., 2012; Aday et al., 2013; Guo et al., 2013; Aday and Caner, 2014).

Electrolyzed water (EW), both acidic and neutral types, is a recent alternative sanitizing and antimicrobial treatment utilized in agriculture and in food industry (Artés et al., 2009). EW is obtained by adding $\mathrm{NaCl}$ to tap water in a chamber with a separating polyester membrane and conducting an electric current across an anode and a cathode. The EW shows antimicrobial properties due to its low $\mathrm{pH}(2.3-2.7)$, its high oxidation- 
reduction potential $(>1000 \mathrm{mV})$ and because it also contains active oxidizers like hypochlorous acid (Kim et $a l ., 2000)$. The main advantage of $\mathrm{EW}$ is its safety, in fact, it is not corrosive to skin, mucous membranes and organic material. Thus, it is environmentally friendly and not potentially dangerous for human health (Huang et al., 2008). The efficacy of EW in reducing microorganism as well as the main foodborne pathogens associated with fresh-cut fruit and vegetables has been reported (Hung et al., 2010; Rahman et al., 2011; Gómez-López et al., 2013).

Some innovative research showed that extract of bamboo incorporated in edible coatings or dissolved in dipping solution improves the storage life of food, due to its antibacterial and antioxidative activity (Jun et al., 2004; Quitain et al., 2004). In particular, the active ingredient is 2,6-dimethoxy-1,4-benzoquinone showed a strong antibacterial effect (Tanaka et al., 2011; Afrin et al., 2012; Tanaka et al., 2013).

Considering the many post-harvest treatments applicable to blueberries, the aim of this work was to evaluate the effects of aqueous chlorine dioxide, electrolyzed water and bamboo extract (new commercial product) on physico-chemical characteristics, bioactive components and microbiological quality of fresh blueberries stored under standard commercial conditions.

\section{Materials and methods}

\subsection{Sample preparation}

The blueberries (Vaccinium corymbosum, cv Duke) were harvested at commercial maturity in Peveragno, Cuneo Province, Italy, and transported to University (DISAFA; University of Turin) lab immediately. For the study, fully ripe fruits were selected for their uniform color, size, and absence of physical damage. The samples were subsequently treated, dried, packed and kept at $0^{\circ} \mathrm{C}$ for storage conservation. Three replicates from each treatment were taken on day 1, 5, 10, 15 and $15+3$ for analysis and the average value is reported.

\subsection{Treatments preparation}

A commercially available brand of $\mathrm{ClO}_{2}$ powder was dissolved in mineral water to prepare the solution according to the manufacturer's instructions (SuperTab, Air Aqua, The Netherland). Considering other experimental results (Pao et al., 2007; Colgecen and Aday, 2015), $20 \mathrm{mg} \mathrm{L}^{-1}$ was selected as the aqueous $\mathrm{ClO}_{2}$ treatment concentration.

Electrolyzed water (MEDL, Tehcno3, Italy) was generated with a fow-type electrolysis apparatus (Hyperoxidation Equipment, Model MEDL Serie A, Gruper). This equipment is capable of producing up to 1.500 liters of neutral water electrolyzed in 10 working hours, with a concentration of 2.000 PPM oxidizers agents.

Berry Very ${ }^{\circledR}$ (Takex-labo, Osaka, Japan) is a commercial product based on Bamboo extract obtained from the crushed sheath of the stem of a gramineous Moso bamboo grown in China and Japan, using ethanol extraction.

\subsection{Postharvest treatments}

Four groups of blueberries were respectively treated as follow: (1) mineral water (electrical conductivity 76 $\mu \mathrm{S} / \mathrm{cm}, \mathrm{pH}$ 7.6) as control, (2) aqueous $\mathrm{ClO}_{2}(20 \mathrm{mg}$ $\mathrm{L}^{-1}$ ), (3) Berry Very, and (4) electrolyzed water. The berries were sprayed all over the surface for about 30 seconds with the aqueous solutions. Samples were then air-dried for $30 \mathrm{~min}$ and about 130-150 g of blueberries were put into plastic baskets, clamshell type (13.5 X 9.0 $\mathrm{X} 2.5 \mathrm{~cm}$, perforated, polyethylene terephthalate) and stored at $0^{\circ} \mathrm{C}$.

\subsection{Determination of weight loss}

Samples were numerated at the start of the experiment. Weight loss was measured calculating the difference between the initial and final weight of fruits containers. Results of weight loss were reported as a relative percentage and calculated as Weight loss (\%) = $(($ Initial weight - Final weight $) /$ Initial weight $) \times 100$.

\subsection{Determination of skin color}

The external color was measured on 30 berries per treatments using a Minolta colorimeter CR-400 (Chroma Meter, Minolta, Japan). Chromatic analyses were carried out following the CIELAB system. Values of $\mathrm{L}^{*}$ (brightness), $\mathrm{a}^{*}$ (redness + , greenness ${ }^{-}$) and $\mathrm{b}^{*}$ (yellowness + , blueness ${ }^{-}$) were measured to describe a three-dimensional color space. The color of blueberries was also expressed as chroma or saturation index (SI = $\left.\left(\mathrm{a}^{2}+\mathrm{b}^{2}\right)^{1 / 2}\right)$ and hue angle (hue angle $=\tan -1\left(\mathrm{~b}^{*} / \mathrm{a}^{*}\right)$.

\subsection{Determination of firmness}

Berries samples were randomly selected for analysis and the sample size was of 30 berries each testing, according to Doving et al. (2005). Each berry was considered a replicate. Before the analysis, samples were warmed to room temperature $\left(20^{\circ} \mathrm{C}\right)$ for $3 \mathrm{~h}$, because most fruits and vegetables showed decreasing firmness with increasing temperature (Bourne, 1980). Fruit 
firmness was determined by penetration test using a Texture Analyzer TaxT2i ${ }^{\circledR}$ (Stable Micro System, Godalming, UK). The penetration test was performed in the equatorial part of the blueberry, at a cross-head speed of $3 \mathrm{~mm} / \mathrm{s}$ and with a $3 \mathrm{~mm}$ diameter punch (Chiabrando et al., 2009). A 30-kg load cell was used for firmness determination and the probe was programmed to penetrate $3 \mathrm{~mm}$ into the sample. The maximum penetration force $(\mathrm{N})$, which is related to the firmness of the samples, was the parameter selected for further statistical analysis.

\subsection{Determination of decay incidence}

The percentage of decay incidence was evaluated after 1, 5, 10 and15 days of storage and calculated as Decay incidence $(\%)=($ weight of decayed fruits/total weight) $\times 100$.

\subsection{Determination of total soluble solid content, titratable acidity, and $\mathrm{pH}$}

Total Soluble Solid Content (TSSC, ${ }^{\circ}$ Brix) of blueberry was determined in the juice using a handheld Atago digital refractometer (model PR-32, Atago, Italia, Milan, Italy). Titratable Acidity (TA) and $\mathrm{pH}$ were determined by titrating the juice with $0.1 \mathrm{M} \mathrm{NaOH}$ to $\mathrm{pH}$ 8.1 using an automatic titrator (Titration workstation Titralab AT1000 Series, Radiometer Analytical, Villerbaunne, France). Results were expressed as meq/l.

2.9 Determination of anthocyanins, total phenolics, and antioxidant capacity

Blueberries samples were extracted with methanol, recovered and stored at $-26^{\circ} \mathrm{C}$ (Chiabrando and Giacalone, 2015). The spectrophotometric $\mathrm{pH}$ differential method (Giusti and Wrolstad, 2001) was used to determine total anthocyanins in the methanol extracts. Absorbance was measured using a UV-visible spectrophotometer (U-5100, Hitachi, Japan) at $510 \mathrm{~nm}$ and at $700 \mathrm{~nm}$ in buffers at $\mathrm{pH} 1.0$ and 4.5, the results were calculated as:

\section{A ) [(A510 - A700)pH1.0 - (A510 - A700)pH4.5].}

The results were expressed as milligrams of cyanidin -3-glucoside equivalent per $100 \mathrm{~g}$ of fresh weight and were an average of three replicate measurements per treatment.

The total phenolic content was determined according to the adapted Folin-Ciocalteu method (Waterhouse, 2002). The absorbance was measured using a UV-visible spectrophotometer (U-5100, Hitachi, Japan) at $750 \mathrm{~nm}$. Aqueous solutions of gallic acid were used for calibration. The results are expressed as gallic acid equivalents (GAE)/100 g.

The antioxidant activity of berries was measured using the Ferric Reducing-Antioxidant Power (FRAP) assay. The procedure was based on the report of Kraujalyte et al. (2013). Results were expressed in mmol $\mathrm{Fe}^{2+} * \mathrm{~kg}^{-1}$ fresh fruits.

\subsection{Yeast and mold evaluation}

Total yeasts and molds were examined according to the methods described by the Compendium of Methods for the Microbiological Examination of Foods (Vanderzant and Splittstoesser, 1992). $270 \mathrm{~mL}$ of peptone buffered water (Sigma Italiana SRL, Ozzano Emilia, Italy) was added to $30 \mathrm{~g}$ of fresh blueberries sample in a Stomacher ${ }^{\circledR}$ bag using a blender (Stomacher ${ }^{\circledR} 400$ Circulator, Seward, Worthing, UK). Appropriate dilutions were equipped. Rose Bengal agar (Sigma Italiana SRL, Ozzano Emilia, Italy) was utilized for the yeast and molds evaluations. All the plates were incubated at $30^{\circ} \mathrm{C}$ for 5 days. Microbial counts were expressed as $\log$ colony forming units $\mathrm{g}^{-1}(\log \mathrm{CFU} / \mathrm{g})$.

\subsection{Statistical analysis}

The results were expressed as a mean \pm standard error of the mean and analyzed using STATISTICA (STATISTICA 8.0 software, 2007). One-way analysis of variance followed by Tukey's post hoc test was used to test for significant differences among means. The differences were considered statistically significant at $p \leq 0.05$.

\section{Results and discussion}

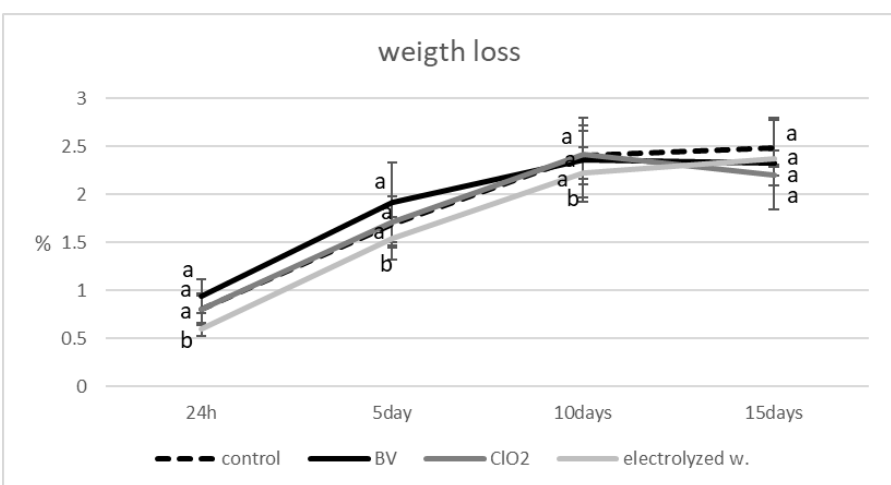

Figure 1. Weight loss (\%) of blueberries sprayed with mineral water (control), Berry Very ${ }^{\circledR}(\mathrm{BV})$, chlorine dioxide $\left(\mathrm{ClO}_{2}\right)$ and electrolyzed water (electrolyzed w.) along with storage at $0^{\circ} \mathrm{C}$. Data are the mean \pm SE. Different letters are significantly different at $p \leq 0.05$ according to Tukey's test.

\subsection{Weight loss}


The weight loss of fresh produce is an important parameter because it leads to economic losses. Fruit and vegetable products generally show symptoms of freshness loss with 3-10\% weight loss (Ben Yehoshua, 1987). In the case of blueberries, fresh fruits become non -marketable when the weight loss is approximately $5 \%$ to $8 \%$ (Sanford et al., 1991) and a weight loss higher than $5 \%$ is the cause of the reduction in retail value of fruits (Ohta et al., 2002). Taking this into account, in this work all the blueberries samples would have still been marketable during the 15 days storage and showed even a lower weight loss if compared with other works (Paniagua et al., 2013; Paniagua, East and Heyes, 2013). Weight loss of treated blueberries is shown in Figure 1. Electrolyzed water influenced positively the reduction of weight loss only in the first 10 days of storage, in fact, at the end of the storage period, the better treatment was chlorine dioxide, followed by Berry Very ${ }^{\circledR}$, electrolyzed water and control, with losses of about $2.5 \%$. Similar results have been reported with aqueous chlorine dioxide for blueberries and cherry tomatoes (Song et al., 2011).

\subsection{Decay incidence}

The postharvest shelf-life of blueberries is also limited by fungal and microbial decay because blueberries are extremely perishable and susceptible. Figure 2 shows the incidence of decay (\%) of blueberries treated and stored at $0^{\circ} \mathrm{C}$ for 15 days. Decay was significantly reduced by all the post-harvest treatments, compared to control berries (Figure 2). In particular, Berry Very ${ }^{\circledR}$ and electrolyzed water treatment significantly $(p \leqslant 0.05)$ delayed the incidence of decay and improved the storage life of the blueberries.

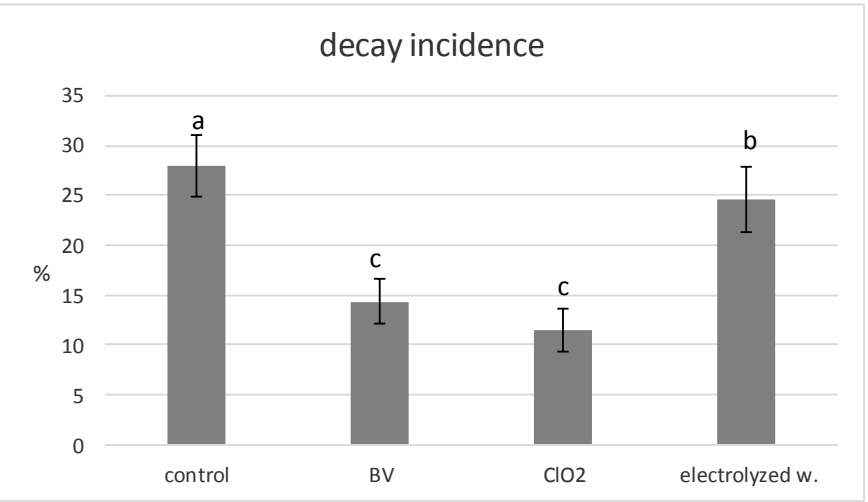

Figure 2. Decay incidence (\%) of blueberries sprayed with mineral water (control), Berry Very ${ }^{\circledR}(\mathrm{BV})$, chlorine dioxide $\left(\mathrm{ClO}_{2}\right)$ and electrolyzed water (electrolyzed w.) after 15 days of storage at $0^{\circ} \mathrm{C}$. Data are the mean $\pm \mathrm{SE}$. Different letters are significantly different at $p \leq 0.05$ according to Tukey's test.

\subsection{Total soluble solid content, titratable acidity, and $\mathrm{pH}$}

Soluble solids are relatively high in blueberries
(Bushway et al., 1983). During storage, total soluble solids content increased significantly in blueberries due to the water losses (Tab.1). Highbush blueberries are characterized by high succinic and citric acid contents, averaging between $75 \%$ and $17 \%$ respectively (Ehlenfeldt et al., 1994). Results in titratable acidity levels of 'Duke' treated blueberries during storage are summarized in Table 1 . Acidity decreased $(p \leqslant 0.05)$ significantly in all blueberry samples during storage. The decreases were significant after 1 day for Berry Very ${ }^{\circledR}$ treated fruits and after 5 days for all the other treatments but the control that was stable until 10 days of storage. Among treatments, Berry Very ${ }^{\circledR}$ treated fruits showed significantly lower values from the first day and until the end of storage. At the end of the storage period control and electrolyzed water treated berries showed the higher acidity values, followed by chlorine dioxide treatment and Berry Very ${ }^{\circledR}$ treated samples. At day 0 , fresh blueberries had a $\mathrm{pH}$ value of $3.69 \pm 0.06$ and the values were almost constant for 15 days of storage for all the treatments evaluated (data not shown).

\subsection{Color}

Skin color is an important factor that affects the visual appearance of fresh fruits and vegetable. Blueberries may lose commodity value if the treatment to reduce microorganisms development leads to a negative color variation (Perkins-Veazie et al., 2008). In this research, the $\mathrm{L}^{*}$ values persisted almost unchanged for control blueberries and electrolyzed water treated samples and slightly decreased in chlorine dioxide berries. By contrast, Berries Very ${ }^{\circledR}$ treated fruits showed the highest variations in $\mathrm{L}^{*}$ values, with the consequence that samples lost their bright color during storage, becoming darker or losing their waxy bloom.

The $\mathrm{h}^{*}$ values of blueberries stored remained almost stable or slightly increased during storage and, after 15 days of storage, reached levels comparable to initial values. The hue of blueberries treated with Berry Very ${ }^{\circledR}$ and stored at $0^{\circ} \mathrm{C}$ for 15 days increased to approximately 321.06. In this case, the blueberries were more blackdark blue than blue, compared with the other treatments.

Just after the treatment (day 0), Berry Very ${ }^{\circledR}$ treated samples showed significant lower Chroma (2.33) values compared with the other treatments (Table 2). In this case, the color of the blueberries became less vivid after the treatment and during the storage.

\subsection{Firmness}

Blueberries firmness is an important quality attribute 
Table 1. Total soluble solids content ( $\left.{ }^{\circ} \mathrm{Brix}\right)$ and titratable acidity (meq/l) of blueberries sprayed with mineral water (control), Berry Very ${ }^{\circledR}(\mathrm{BV})$, chlorine dioxide $\left(\mathrm{ClO}_{2}\right)$ and electrolyzed water (electrolyzed w.) during 15 days of storage at $0{ }^{\circ} \mathrm{C}$. (Day 0: the same sample of blueberries analyzed before the different treatments). Data are the mean $\pm \mathrm{SE}$.

\begin{tabular}{cccccc}
\hline \multicolumn{5}{c}{ Days of Storage } \\
\hline${ }^{\circ}$ Brix & 0 & 1 & 5 & 10 & 15 \\
\hline control & $8.4 \pm 0.15^{\mathrm{Ca}}$ & $8.43 \pm 0.19^{\mathrm{Cc}}$ & $9.03 \pm 0.05^{\mathrm{Bb}}$ & $9.7 \pm 0.26^{\mathrm{ABb}}$ & $10.3 \pm 0.05^{\mathrm{Ab}}$ \\
$\mathrm{BV}$ & $8.4 \pm 0.15^{\mathrm{Ca}}$ & $10.36 \pm 0.49^{\mathrm{Ba}}$ & $10.23 \pm 0.13^{\mathrm{Ba}}$ & $11.4 \pm 0.32^{\mathrm{Aa}}$ & $11.36 \pm 0.18^{\mathrm{Aa}}$ \\
$\mathrm{ClO}_{2}$ & $8.4 \pm 0.15^{\mathrm{Ba}}$ & $9.57 \pm 0.37^{\mathrm{ABab}}$ & $10.03 \pm 0.05^{\mathrm{Aa}}$ & $10 \pm 0.32^{\mathrm{Ab}}$ & $9.87 \pm 0.22^{\mathrm{Ab}}$ \\
electrolyzed w. & $8.4 \pm 0.15^{\mathrm{Ba}}$ & $8.63 \pm 0.31^{\mathrm{Bbc}}$ & $8.9 \pm 0.08^{\mathrm{ABb}}$ & $9.53 \pm 0.05^{\mathrm{Ab}}$ & $9.97 \pm 0.05^{\mathrm{Ab}}$ \\
\hline meq/1 & 0 & 1 & 5 & 10 & 15 \\
\hline control & $100.03 \pm 14.05^{\mathrm{Aa}}$ & $116.12 \pm 14.38^{\mathrm{Aa}}$ & $99.19 \pm 6.58^{\mathrm{Aa}}$ & $75.11 \pm 2.17^{\mathrm{Ba}}$ & $73.25 \pm 3.57^{\mathrm{Ba}}$ \\
$\mathrm{BV}$ & $100.03 \pm 14.05^{\mathrm{Aa}}$ & $59.35 \pm 13.43^{\mathrm{Bb}}$ & $61.52 \pm 14.99^{\mathrm{Bb}}$ & $60.37 \pm 10.88^{\mathrm{Bb}}$ & $59.79 \pm 5.42^{\mathrm{Bb}}$ \\
$\mathrm{ClO}_{2}$ & $100.03 \pm 14.05^{\mathrm{Aa}}$ & $115.2 \pm 11.18^{\mathrm{Aa}}$ & $65.37 \pm 9.41^{\mathrm{Bb}}$ & $73.9 \pm 2.67^{\mathrm{Ba}}$ & $72.24 \pm 6.15^{\mathrm{Bab}}$ \\
electrolyzed w. & $100.03 \pm 14.05^{\mathrm{Aa}}$ & $100.09 \pm 15.98^{\mathrm{Aa}}$ & $87.05 \pm 5.67^{\mathrm{Bab}}$ & $73.85 \pm 3.30^{\mathrm{Ca}}$ & $73.01 \pm 2.09^{\mathrm{Ca}}$ \\
\hline
\end{tabular}

a-b Mean in the same column with different letters are significantly different at $p \leq 0.05$ according to Tukey's test.

A-B Mean in the same row with different letters are significantly different at $p \leq 0.05$ according to Tukey's test.

Table 2. Color parameters of blueberries sprayed with mineral water (control), Berry Very ${ }^{\circledR}(\mathrm{BV})$, chlorine dioxide $\left(\mathrm{ClO}_{2}\right)$ and electrolyzed water (electrolyzed w.) during 15 days of storage at $0^{\circ} \mathrm{C}$. (Day 0 : the same sample of blueberries analyzed before the different treatments). Data are the mean $\pm \mathrm{SE}$.

\begin{tabular}{|c|c|c|c|c|c|}
\hline & & & Days of Storage & & \\
\hline $\mathrm{C}^{*}$ & 0 & 1 & 5 & 10 & 15 \\
\hline control & $5.11 \pm 0.85^{\mathrm{Aba}}$ & $4.76 \pm 0.86^{\mathrm{Ba}}$ & $4.67 \pm 0.87^{\mathrm{Bb}}$ & $5.79 \pm 0.72^{\mathrm{Aa}}$ & $4.51 \pm 0.83^{\mathrm{Ba}}$ \\
\hline BV & $5.11 \pm 0.85^{\mathrm{Aa}}$ & $3.69 \pm 0.73^{\mathrm{Bb}}$ & $4.40 \pm 1.01^{\mathrm{Abc}}$ & $3.56 \pm 0.61^{\mathrm{Bc}}$ & $3.41 \pm 0.61^{\mathrm{Bb}}$ \\
\hline $\mathrm{ClO}_{2}$ & $5.11 \pm 0.85^{\mathrm{Aa}}$ & $4.52 \pm 0.78^{\mathrm{Ba}}$ & $5.76 \pm 0.53^{\mathrm{Aa}}$ & $5.16 \pm 0.77^{\mathrm{Ab}}$ & $4.52 \pm 0.85^{\mathrm{Ba}}$ \\
\hline electrolyzed w. & $5.11 \pm 0.85^{\mathrm{Aa}}$ & $3.35 \pm 0.85^{\mathrm{Ab}}$ & $4.11 \pm 0.93^{\mathrm{Ac}}$ & $3.91 \pm 0.89^{\mathrm{Ac}}$ & $4.16 \pm 1.13^{\mathrm{Aa}}$ \\
\hline${ }^{\circ} \mathrm{h}$ & 0 & 1 & 5 & 10 & 15 \\
\hline control & $288.47 \pm 14.51^{\mathrm{Aa}}$ & $294.73 \pm 15.4^{\mathrm{Aa}}$ & $293.71 \pm 12.46^{\text {Aab }}$ & $286.34 \pm 8.56^{\mathrm{Ab}}$ & $297.95 \pm 19.47^{\mathrm{Ab}}$ \\
\hline BV & $288.47 \pm 14.51^{\mathrm{Aa}}$ & $312.41 \pm 16.94 \mathrm{Aa}$ & $296.21 \pm 11.29^{\mathrm{Aab}}$ & $310.60 \pm 13.96^{\mathrm{Aa}}$ & $321.06 \pm 21.77^{\mathrm{Aa}}$ \\
\hline $\mathrm{ClO}_{2}$ & $288.47 \pm 14.51^{\mathrm{Aa}}$ & $301.42 \pm 16.35^{\mathrm{Aa}}$ & $287.07 \pm 10.53^{\mathrm{Ab}}$ & $286.10 \pm 6.41^{\mathrm{Ab}}$ & $297.21 \pm 17.21^{\mathrm{Ab}}$ \\
\hline electrolyzed w. & $288.47 \pm 14.51^{\mathrm{Aa}}$ & $306.98 \pm 21.74 \mathrm{Aa}$ & $300.24 \pm 18.66^{\mathrm{Aa}}$ & $304.92 \pm 20.67^{\text {Aab }}$ & $308.65 \pm 24.56^{\mathrm{Ab}}$ \\
\hline $\mathrm{L}^{*}$ & 0 & 1 & 5 & 10 & 15 \\
\hline control & $30.30 \pm 3.84^{\mathrm{Aa}}$ & $26.25 \pm 3.47^{\mathrm{Ba}}$ & $29.09 \pm 2.71^{\mathrm{Aa}}$ & $29.53 \pm 2.84^{\mathrm{Aa}}$ & $29.39 \pm 3.44^{\mathrm{Aa}}$ \\
\hline BV & $30.30 \pm 3.84^{\mathrm{Aa}}$ & $20.21 \pm 2.05^{\mathrm{Cb}}$ & $20.21 \pm 2.06^{\mathrm{Cc}}$ & $20.76 \pm 2.14^{\mathrm{Cc}}$ & $22.98 \pm 2.76^{\mathrm{Bc}}$ \\
\hline $\mathrm{ClO}_{2}$ & $30.30 \pm 3.84^{\mathrm{Aa}}$ & $26.02 \pm 4.31^{\mathrm{Ca}}$ & $28.45 \pm 2.62^{\mathrm{Ba}}$ & $31.01 \pm 2.91 \mathrm{Aa}$ & $28.62 \pm 2.63^{\mathrm{Bab}}$ \\
\hline electrolyzed w. & $30.30 \pm 3.84^{\mathrm{Aa}}$ & $25.6 \pm 3.81^{\mathrm{Aba}}$ & $24.00 \pm 3.09^{\mathrm{Bb}}$ & $25.59 \pm 2.91^{\mathrm{Bb}}$ & $27.23 \pm 3.77^{\mathrm{Ab}}$ \\
\hline
\end{tabular}

$\mathrm{a}-\mathrm{b}$ Mean in the same column with different letters are significantly different at $p \leq 0.05$ according to Tukey's test.

A-B Mean in the same row with different letters are significantly different at $p \leq 0.05$ according to Tukey's test.

Table 3. Firmness of blueberries sprayed with mineral water (control), Berry Very® $(\mathrm{BV})$, chlorine dioxide $\left(\mathrm{ClO}_{2}\right)$ and electrolyzed water (electrolyzed w.) during 15 days of storage at $0^{\circ} \mathrm{C}$. (Day 0 : the same sample of blueberries analyzed before the different treatments). Data are the mean $\pm \mathrm{SE}$.

\begin{tabular}{cccccc}
\hline \multicolumn{5}{c}{ Days of Storage } \\
\hline $\mathrm{N}$ & 0 & 1 & 5 & 10 & 15 \\
\hline control & $1.88 \pm 0.43^{\mathrm{Aa}}$ & $1.84 \pm 0.37^{\mathrm{Aa}}$ & $1.85 \pm 0.49^{\mathrm{Aa}}$ & $1.55 \pm 0.44^{\mathrm{Bab}}$ & $1.56 \pm 0.46^{\mathrm{Ba}}$ \\
$\mathrm{BV}$ & $1.88 \pm 0.43^{\mathrm{Aa}}$ & $1.74 \pm 0.43^{\mathrm{ABa}}$ & $1.44 \pm 0.49^{\mathrm{Bb}}$ & $1.40 \pm 0.61^{\mathrm{Bb}}$ & $1.10 \pm 0.44^{\mathrm{Cb}}$ \\
$\mathrm{ClO}_{2}$ & $1.88 \pm 0.43^{\mathrm{Aa}}$ & $1.83 \pm 0.38^{\mathrm{Aa}}$ & $1.71 \pm 0.63^{\mathrm{Aab}}$ & $1.63 \pm 0.53^{\mathrm{ABa}}$ & $1.55 \pm 0.75^{\mathrm{Ba}}$ \\
electrolyzed w. & $1.88 \pm 0.43^{\mathrm{Aa}}$ & $1.89 \pm 0.40^{\mathrm{Aa}}$ & $1.71 \pm 0.33^{\mathrm{ABa}}$ & $1.65 \pm 0.42^{\mathrm{Aa}}$ & $1.56 \pm 0.47^{\mathrm{Ba}}$ \\
\hline
\end{tabular}

$\mathrm{a}-\mathrm{b}$ Mean in the same column with different letters are significantly different at $p \leq 0.05$ according to Tukey's test.

A-B Mean in the same row with different letters are significantly different at $p \leq 0.05$ according to Tukey's test. 
Table 4. Total anthocyanin, phenolics and antioxidant capacity of blueberries sprayed with mineral water (control), Berry Very ${ }^{\circledR}$ (BV), chlorine dioxide $\left(\mathrm{ClO}_{2}\right)$ and electrolyzed water (electrolyzed w.) during 15 days of storage at $0^{\circ} \mathrm{C}$. (Day 0: the same sample of blueberries analyzed before the different treatments). Data are the mean $\pm \mathrm{SE}$.

Days of Storage

\begin{tabular}{cccccc}
\hline $\begin{array}{c}\text { Total anthocyanin (mg cyanidin } \\
\text {-3-O-gluc eq/100 g f.w.) }\end{array}$ & 0 & 1 & 5 & 10 & 15 \\
\hline control & $87.75 \pm 2.35^{\mathrm{Ca}}$ & $108.29 \pm 2.31^{\mathrm{Ba}}$ & $116.91 \pm 3.08^{\mathrm{Ba}}$ & $111.58 \pm 5.25^{\mathrm{Ba}}$ & $145.72 \pm 2.35^{\mathrm{Aa}}$ \\
$\mathrm{BV}$ & $87.75 \pm 2.35^{\mathrm{Ca}}$ & $97.38 \pm 4.49^{\mathrm{Ba}}$ & $116.09 \pm 2.43^{\mathrm{Ba}}$ & $128.58 \pm 5.32^{\mathrm{Aa}}$ & $150.84 \pm 3.38^{\mathrm{Aa}}$ \\
$\mathrm{ClO}_{2}$ & $87.75 \pm 2.35^{\mathrm{Ca}}$ & $99.16 \pm 3.37^{\mathrm{Ca}}$ & $112.09 \pm 2.05^{\mathrm{Ba}}$ & $131.37 \pm 2.32^{\mathrm{Aa}}$ & $132.20 \pm 3.22^{\mathrm{Aa}}$ \\
electrolyzed w. $^{\mathrm{Ba}}$ & $87.75 \pm 2.35^{\mathrm{Ba}}$ & $102.71 \pm 3.31^{\mathrm{Aba}}$ & $97.24 \pm 5.38^{\mathrm{Ba}}$ & $124.01 \pm 2.25^{\mathrm{Aa}}$ & $150.74 \pm 6.32^{\mathrm{Aa}}$ \\
\hline
\end{tabular}

Total phenolics (mg gallic acid eq/100 g f.w.)

0 1

10

15

\begin{tabular}{cccccc}
\hline control & $205.91 \pm 14.05^{\mathrm{Ba}}$ & $208.42 \pm 14.38^{\mathrm{Bb}}$ & $195.88 \pm 6.58^{\mathrm{Ba}}$ & $242.20 \pm 2.17^{\mathrm{Aa}}$ & $259.05 \pm 3.57^{\mathrm{Aa}}$ \\
$\mathrm{BV}$ & $205.91 \pm 14.05^{\mathrm{Ba}}$ & $229.39 \pm 13.43^{\mathrm{Ba}}$ & $216.84 \pm 14.99^{\mathrm{Ba}}$ & $238.98 \pm 10.88$ & $260.12 \pm 5.42^{\mathrm{Aa}}$ \\
$\mathrm{ClO}_{2}$ & $205.91 \pm 14.05^{\mathrm{Ba}}$ & $212.99 \pm 11.18^{\mathrm{Ba}}$ & $209.32 \pm 9.41^{\mathrm{Ba}}$ & $233.42 \pm 2.67^{\mathrm{Ab}}$ & $241.84 \pm 6.15^{\mathrm{Aab}}$ \\
electrolyzed w. & $205.91 \pm 14.05^{\mathrm{Aa}}$ & $215.68 \pm 15.98^{\mathrm{Aa}}$ & $212.99 \pm 5.67^{\mathrm{Aa}}$ & $228.58 \pm 3.30^{\mathrm{Ab}}$ & $220.34 \pm 2.09^{\mathrm{Ab}}$ \\
\hline \begin{tabular}{c}
\multirow{2}{*}{ Antioxidant capacity (mmol } \\
$\left.\mathrm{Fe}^{2+} / \mathrm{kg}\right)$
\end{tabular} & 0 & 1 & 5 & 10 & \multirow{2}{*}{15} \\
\hline control $_{\mathrm{BV}}$ & $38.82 \pm 1.05^{\mathrm{Aa}}$ & $29.09 \pm 1.38^{\mathrm{Ba}}$ & $30.72 \pm 1.58^{\mathrm{Ba}}$ & $30.74 \pm 2.17^{\mathrm{Ba}}$ & $24.85 \pm 3.57^{\mathrm{Ba}}$ \\
$\mathrm{Ba}$ & $38.82 \pm 1.05^{\mathrm{Aa}}$ & $30.11 \pm 3.43^{\mathrm{Ba}}$ & $28.54 \pm 2.99^{\mathrm{Ba}}$ & $30.78 \pm 1.88^{\mathrm{Ba}}$ & $25.51 \pm 1.42^{\mathrm{Ba}}$ \\
$\mathrm{ClO}_{2}$ & $38.82 \pm 1.05^{\mathrm{Aa}}$ & $29.27 \pm 1.18^{\mathrm{Ba}}$ & $30.13 \pm 2.41^{\mathrm{Ba}}$ & $26.88 \pm 2.67^{\mathrm{Ba}}$ & $26.34 \pm 1.15^{\mathrm{Ba}}$ \\
electrolyzed w. & $38.82 \pm 1.05^{\mathrm{Aa}}$ & $29.35 \pm 1.98^{\mathrm{Ba}}$ & $28.69 \pm 0.67^{\mathrm{Ba}}$ & $28.38 \pm 1.30^{\mathrm{Ba}}$ & $25.91 \pm 2.09^{\mathrm{Ba}}$ \\
\hline
\end{tabular}

a-b Mean in the same column with different letters are significantly different at $p \leq 0.05$ according to Tukey's test.

A-B Mean in the same row with different letters are significantly different at $p \leq 0.05$ according to Tukey's test.

and an excessive softening is one of the main factors reducing fruit quality and limiting its commercialization for fresh consumption (Angeletti et al., 2010). As shown in Table 3, firmness of blueberries declined gradually in all the samples. After 5 days of storage, Berry Very ${ }^{\circledR}$ samples showed significantly lower weight losses compared with other treatments. These results indicated that aqueous treatments could not delay the softening of blueberries during storage, probably because these treatments do not interact positively with the cell wall enzymatic degradation during postharvest storage.

\subsection{Anthocyanins, total phenolics, and antioxidant capacity}

Anthocyanins content increased significantly $(p \leqslant 0.05)$ during storage, but without significant differences among the treatments evaluated. The values at day 0 , ranged from $87.75 \mathrm{mg} / 100 \mathrm{~g}$ (cyanidin 3-gluc) to $150 \mathrm{mg} / 100 \mathrm{~g}$ in Berry Very ${ }^{\circledR}$ and electrolyzed water samples, $145 \mathrm{mg} / 100 \mathrm{~g}$ in the control and $132 \mathrm{mg} / 100 \mathrm{~g}$ in chloride dioxide samples after 15 days of storage (Table 4).

The same results were obtained for total phenols content. Phenols increase significantly $(\mathrm{p} \leqslant 0.05)$ during storage period from $205.91 \mathrm{mg} / 100 \mathrm{~g}$ (gallic acid) at day
0 , to $245 \mathrm{mg} / 100 \mathrm{~g}$ (gallic acid) on average, after 15 days of storage. After 10 and 15 days of storage, control samples showed significantly $(\mathrm{p} \leqslant 0.05)$ higher values compared with others treatments, on the contrary, electrolyzed water samples showed the lowest values. Antioxidant capacity values decreased after 1 day of storage and then remained almost stable during (Table 4).

Table 5. Microbial counts of blueberries sprayed with mineral water (control), Berry Very ${ }^{\circledR}(\mathrm{BV})$, chlorine dioxide $\left(\mathrm{ClO}_{2}\right)$ and electrolyzed water (electrolyzed w.) during 15 days of storage at $0^{\circ} \mathrm{C}$. (Day 0: the same sample of blueberries analyzed before the different treatments).

\begin{tabular}{cccccc}
\hline Yeast $(\mathrm{CFU} / \mathrm{g})$ & 0 & 1 & 5 & 10 & 15 \\
\hline control & 3.43 & 2.96 & 3.72 & 4.11 & 4.6 \\
$\mathrm{BV}$ & 3.43 & 5.65 & 2.9 & 4.28 & 5.04 \\
$\mathrm{ClO}_{2}$ & 3.43 & 3.11 & 3 & 4.15 & 2.81 \\
electrolyzed w. & 3.43 & 2.72 & 2.45 & 2.45 & 2.15 \\
\hline Mold $(\mathrm{CFU} / \mathrm{g})$ & 0 & 1 & 5 & 10 & 15 \\
\hline control & 2.34 & 2.3 & 2.38 & 2.66 & 3.26 \\
$\mathrm{BV}$ & 2.34 & 1 & 1.6 & 1.78 & 4.3 \\
$\mathrm{ClO}_{2}$ & 2.34 & 2.4 & 3.43 & 2.51 & 2.68 \\
electrolyzed w. & 2.34 & 1.9 & 2.26 & 2.2 & 3.26 \\
\hline
\end{tabular}

\subsection{Yeast and mold}

Microbial counts of yeasts and molds throughout the 
storage of treated blueberries are shown in Table 5. The initial microbial count was $3.43 \log \mathrm{CFU} \mathrm{g}^{-1}$ for yeasts and $2.34 \log \mathrm{CFU} \mathrm{g}{ }^{-1}$ for molds. During the storage period, increases in the microbial count were observed in all the samples. Aqueous treatments tended to reduce microbial counts of yeasts and molds for all the storage period, except for Berry Very ${ }^{\circledR}$ treatment. In this case, after 15 days of storage samples showed a higher level of yeasts and molds compared with the other treatments.

Treatment with electrolyzed water showed a higher disinfectant effect on yeasts proliferation compared to the other treatments. On the contrary, chlorine dioxide treatment was active in the reduction of molds, in particular at the end of the storage period, according to Aday and Caner (2014) on strawberries and Zhang et al. (2015) on blueberries.

\section{Conclusion}

In this paper, we presented the effect of chlorine dioxide, electrolyzed water and Berry Very® on blueberry quality during the postharvest storage period. Among the individual treatments, at commercial level, Berry Very ${ }^{\circledR}$ and electrolyzed water showed the best results in term of lower weight loss, postharvest decay and microbial counts. On the contrary, if we considered the blueberry quality, Berry Very ${ }^{\circledR}$ affected negatively berries color, acidity level, and firmness. All the treatments did not influence the anthocyanin content, polyphenol, and antioxidant activity. In future, confirmation of this novel treatments efficacy in other fruit and berry fruit will be necessary to gain a better knowledge on their preserving fruit quality and safety for future commercial purposes.

\section{References}

Aday, M.S., Buyukcan, M.B. and Caner, C. (2013). Maintaining the quality of strawberries by combined effect of aqueous chlorine dioxide with modified atmosphere packaging. Journal of Food Processing and Preservation, 37, 568-581.

Aday, M.S. and Caner, C. (2014). Individual and combined effects of ultrasound, ozone and chlorine dioxide on strawberry storage life. LWT - Food Science and Technology, 57(1), 344-351.

Afrin, T., Tsuzuki, T., Kanwar, R.K. and Wang, X. (2012). The origin of the antibacterial property of bamboo. The Journal of the Textile Institute, 103(8), 844-849.

Angeletti, P., Castagnasso, H., Miceli, E., Terminiello,
L., Concellón, A., Chaves, A. and Vicente, A.R. (2010). Effect of preharvest calcium applications on postharvest quality, softening and cell wall degradation of two blueberry (Vaccinium corymbosum) varieties. Postharvest Biology and Technology, 58, 98-103.

Artés, F., Gómez, P., Aguayo, E., Escalona, V. and Artés -Hernández, F. (2009). Sustainable sanitation techniques for keeping quality and safety of fresh-cut plant commodities. Postharvest Biology and Technology, 51(3), 287-296.

Ben Yehoshua, S. (1987). Transpiration, water stress, and gas Exchange. In Weichmann, J. (Ed.). Postharvest physiology of vegetables, p. 113. New York: Marcel Dekker.

Bourne, M.C. (1980). Textural evaluation of horticultural crops. HortScience, 15, 51-56.

Bunea, A., Rugină, D., Sconţa, Z., Pop, R.M., Pintea, A., Socaciu, C., Tăbăran, F., Grootaert, C., Struijs, K. and VanCamp, J. (2013). Anthocyanin determination in blueberry extracts from various cultivars and their antiproliferative and apoptotic properties in B16-F10 metastatic murine melanoma cells. Phytochemistry, 95, 436-444.

Bushway, R.J., Mc Gann, D.F, Cook, W.P. and Bushway A.A. (1983). Mineral and vitamin content of lowbush blueberries (Vaccinium angustifolium Ait.). Journal of Food Science, 48(6), 1878-1880.

Cantín, C.M., Minas, I.S., Goulas, V., Jiménez, M., Manganaris, G.A., Michailides, T.J. and Crisosto C.H. (2012). Sulfur dioxide fumigation alone or in combination with $\mathrm{CO} 2$-enriched atmosphere extends the market life of highbush blueberry fruit. Postharvest Biology and Technology, 67, 84-91.

Chen, Z. and Zhu, C. (2011). Combined effects of aqueous chlorine dioxide and ultrasonic treatments on postharvest storage quality of plum fruit (Prunus salicina L.). Postharvest Biology and Technology, 61 (2), 117-123.

Chen, Z., Zhu, C. and Han, Z. (2011). Effects of aqueous chlorine dioxide treatment on nutritional components and shelf-life of mulberry fruit (Morus alba L.). Journal of Bioscience and Bioengineering, 111, 675681.

Chiabrando, V., Giacalone, G. and Rolle, L. (2009). Mechanical behaviour and quality traits of highbush blueberry during postharvest storage. Journal of the Science of Food and Agriculture, 89, 989-992.

Chiabrando, V. and Giacalone, G. (2016). Effects of edible coatings on quality maintenance of fresh-cut 
nectarines. Emirates Journal of Food and Agriculture, 28, 201-207.

Chiabrando, V. and Giacalone, G. (2015). Anthocyanins, phenolics and antioxidant capacity after fresh storage of blueberry treated with edible coatings. International Journal of Food Science and Nutrition, $33,248-253$

Chiabrando, V., Peano, C., Beccaro, G., Bounous, G. and Rolle, L. (2006). Postharvest quality of highbush blueberry (Vaccinium Corymbosum L.) cultivars in relation to storage methods. Acta Horticulturae, 715, 545-552.

Colgecen, I. and Aday, M.S. (2015). The efficacy of the combined use of chlorine dioxide and passive modified atmosphere packaging on sweet cherry quality. Postharvest Biology and Technology, 109, 10-19.

Connor, A.M., Luby, J.J., Hancock, J.F., Berkheimer, S. and Hanson E.J. (2002). Changes in fruit antioxidant activity among blueberry cultivars during coldtemperature storage. Journal of Agricultural and Food Chemistry, 50, 893-898.

Doving, A., Mage, F. and Vestrheim, S. (2005). Methods for testing strawberry fruit firmness: a review. Small Fruit Review, 4, 11-34.

Du, J., Han, Y. and Linton, R.H. (2002). Inactivation by chlorine dioxide gas $\left(\mathrm{ClO}_{2}\right)$ of Listeria monocytogenes spotted onto different apple surfaces. Journal of Food Protection, 19, 481-490.

Duan, J., Wu, R., Strik, B.C. and Zhao, Y. (2011). Effect of edible coatings on the quality of fresh blueberries (Duke and Elliott) under commercial storage conditions. Postharvest Biology and Technology, 59, 71-79.

Ehlenfeldt, M.K., Meredith, F.I. and Ballington J.R. (1994). Unique organic acid profile of Rabbiteye vs. highbush blueberries. HortScience, 29, 230-240.

Fan, L., Forney, C.F., Song, J., Doucette, C., Jordan, M.A, MCrae, K.B. and Walker B.A. (2008). Effect of Hot Water Treatments on Quality of Highbush Blueberries. Journal of Food Science, 73(6), 292297.

Fangxu, X., Shenghou, W., Jie, X., Shiyang, L. and Guode, L. (2016). Effects of combined aqueous chlorine dioxide and UV-C on shelf-life quality of blueberries. Postharvest Biology and Technology, $117,125-131$.

Giusti, M.M. and Wrolstad, R.E. (2001). Unit F1.2: Anthocyanins. Characterization and Measurement with UV-Visible Spectroscopy. In Wrolstad, R.E.
(Eds). Current Protocols in Food Analytical Chemistry, p. 1-13. New York: John Wiley and Sons.

Gómez-López, V.M., Rajkovic, A., Ragaert, P., Smigic, N. and Devlieghere, F. (2009). Chlorine dioxide for minimally processed produce preservation: a review. Trends in Food Science and Technology, 20(1), 1726.

Gómez-López, V.M., Marín, A., Medina-Martínez, M.S., Gil, M.I. and Allende, A. (2013). Generation of trihalomethanes with chlorine-based sanitizers and impact on microbial: nutritional and sensory quality of baby spinach. Postharvest Biology and Technology, 85, 210-217.

Guo, Q., Lv, X., Xu, F., Zhang, Y., Wang, J., Lin, H. and Wu, B. (2013). Chlorine dioxide treatment decreases respiration and ethylene synthesis in fresh-cut 'Hami' melon fruit. International Journal of Food Science and Technology, 48, 1775-1782.

Huang, Y.R., Hung, Y.C., Hsu, S.Y., Huang, Y.W. and Hwang, D.F. (2008). Application of electrolyzed water in the food industry. Food Control, 19, 32945.

Hung, Y.C., Tilly, P. and Kim, C. (2010). Efficacy of electrolyzed oxidizing (eo) water and chlorinated water for inactivation of Escherichia coli $157: \mathrm{H} 7$ on strawberries and broccoli. Journal of Food Quality, $33,559-577$.

Keskinen, L.A., Burke, A. and Annous, B.A. (2009). Efficacy of chlorine, acidic electrolyzed water and aqueous chlorine dioxide solutions to decontaminate Escherichia coli O157: H7 from lettuce leaves. International Journal of Food Microbiology, 132, 134-140.

Kim, C., Hung, Y.C. and Brackett, R.E. (2000). Roles of oxidation-reduction potential in electrolyzed oxidizing and chemically modified water for the inactivation of food-related pathogens. Journal of Food Protection, 63, 19-24.

Kraujalyte, V., Venskutonis, P.R., Pukalskas, A., Česoniene, L. and Daubaras, R. (2013). Antioxidant properties and polyphenolic compositions of fruits from different European cranberry bush (Viburnum opulus L.) genotypes. Food Chemistry, 141, 36953702.

Jun, M., Tohru, U., Jianzhang, L. and Takeshi, F. (2004). Identification and Evaluation of Antioxidant Activities of Bamboo Extracts. Forestry Studies in China, 6(2), 1-5.

Ohta, H., Shiina, T. and Sasaki, K. (2002). Dictionary of 
freshness and shelf-life of fruit. Tokyo: Science Forum Co. Ltd.

Paniagua, A.C., East, A.R., Hindmarsh, J.P. and Heyes, J.A. (2013). Moisture loss is the major cause of firmness change during postharvest storage of blueberry. Postharvest Biology and Technology, 79, 13-19.

Paniagua, A.C., East, A.R. and Heyes, J.A. (2013). Effects of delays in cooling of blueberry quality outcomes. ActaHorticolturae 1012, 1493-1498.

Pao, S., Kelsey, D.F., Khalid, M.F. and Ettinger M.R. (2007). Using aqueous chlorine dioxide to prevent contamination of tomatoes with Salmonella enterica and Erwinia carotovora during fruit washing. Journal of Food Protection, 70, 629-634.

Perkins-Veazie, P., Collins, J.K. and Howard, L. (2008). Blueberry fruit response to postharvest application of ultraviolet radiation. Postharvest Biology and Technology, 47, 280-285.

Quitain, A.T., Katoh, S. and Moriyoshi, T. (2004). Isolation of Antimicrobials and Antioxidants from Moso-Bamboo (Phyllostachys Heterocycla) by Supercritical $\mathrm{CO}_{2}$ Extraction and Subsequent Hydrothermal Treatment of the Residues. Industrial \& Engineering Chemistry Research, 43(4), 10561060.

Rahman, S.M.E., Jin, Y.G. and Oh D.H. (2011). Combination treatment of alkaline electrolyzed water and citric acid with mild heat to ensure microbial safety shelf-life and sensory quality of shredded carrots. Food Microbiology, 28, 484-491.

Sanford, K.A., Lidster, P.D., McRae, K.B., Jackson, E.D., Lawrence, R.A., Stark, R. and Prange R.K. (1991). Lowbush blueberry quality changes in response to mechanical damage and storage temperature. Journal of the American Society of Horticultural Science, 116, 47-51.

Shin, Y.J., Song, H.Y. and Song, B.K. (2012). Effect of a combined treatment of rice bran protein film packaging with aqueous chlorine dioxide washing and ultraviolet-C irradiation on the postharvest quality of 'Goha' strawberries. Journal of Food Engineering, 113, 374-379.

Song, H.J., Choi, D.W. and Song, K.B. (2011). Effect of aqueous chlorine dioxide and UV-C treatment on the microbial reduction and color of cherry tomatoes. Horticulture, Environment and Biotechnology, 5, 488-493.

Tanaka, A., Kim, H.J., Oda, S., Shimizu, K. and Kondo, R. (2011). Antibacterial activity of moso bamboo shoot skin (Phyllostachys pubescens) against Staphylococcus aureus. Journal of Wood Science, 57, 542-544.

Tanaka, A., Shimizu, K. and Kondo, R.J. (2013). Antibacterial compounds from shoot skins of moso bamboo (Phyllostachys pubescens). Wood Science, 59, 155-159.

Waterhouse, A.L. (2002). Polyphenolics: Determination of total phenolics. In Wrolstad, R.E. (Ed.). Current protocols in food analytical chemistry, Il.1.1-Il.1.8. New York: John Wiley and Sons.

Zhang, L., Yan, Z., Hanson, E.J. and Ryser, E.T. (2015). Efficacy of chlorine dioxide gas and freezing rate on the microbiological quality of frozen blueberries. Food Control, 47, 114-119.

Zheng, Y., Wang, C.Y., Wang, S.Y. and Zheng, W. (2003). Effect of high-oxygen atmospheres on blueberry phenolics, anthocyanins, and antioxidant capacity. Journal of the Agriculture and Food Chemistry, 51, 7162-7169. 